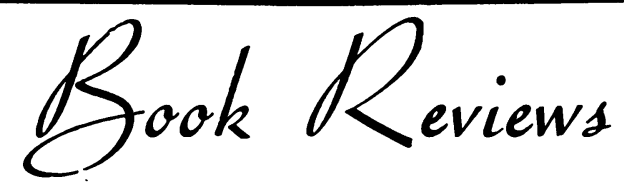

\section{SIR WILLIAM ARBUTHNOT LANE, Bt., C.B., M.S.}

By T. B. Layton, D.S.O., M.S. Pp. viii +128 .

Edinburgh: E. S. Livingstone Ltd. 1956. 2 rs.

One of the difficulties facing the author of the biography of a surgeon is to step back in time and to present his subject's ideas and work against the background of surgical knowledge at the relevant period. Mr. Layton succeeds admirably in so doing and by putting before us the facts as seen through Lane's eyes gives a completely unbiased account of the life and activities of this unique surgeon, in which are revealed not only his many triumphs, but also his weaknesses and disappointments. It is desirable that all who aspire to the title surgeon should be cognizant of the methods of the great ones of the past. Lane's successes were the result of painstaking observation and logical deduction. Who but he would have paid special visits to the docks to see for himself the duties of a stevedore dissatisfied with the end result of a fracture, and of a trimmer whose dissected spine presented peculiarities? This little book is full of interest and well worth reading, not only for the information it contains, but also for the thought which it stimulates.

A.S.

\section{LAW RELATING TO HOSPITALS AND KINDRED INSTITUTIONS}

By S. R. Speller, LL.B. Third Edition. Pp. xxxix + 649. London: H. K. Lewis \& Co. 1956. 70 s.

This valuable book, well known to hospital administrators, has again been brought up to date with the appearance of a third edition, in which the chapters on liability for injuries to patients and on master and servant have been rewritten in the light of recent judgments and others suitably amended. Though covering virtually the whole field of hospital administration and addressed primarily to those so engaged, the chapters dealing with the responsibilities of medical staff are lucidly written and offer sound advice to the clinician upon the problems which may confront him, often at short notice. The excellent index and non-technical language make this a handy reference book for members of both administrative and medical staffs of hospitals.

\section{THE PRACTICE OF MEDICINE}

Edited by John S. Richardson, M.V.O., M.A., M.D., F.R.C.P. Pp. viii + 1076, with 86 illustrations. London: J. and A. Churchill Ltd. I956. 40s.

This is a comprehensive textbook of medicine intended primarily for undergraduate students and written by some 14 contributors, well known in their respective subjects.

The book is very readable and includes many useful photographs and diagrams. In addition to the usual clinical medical subjects, there are sections on poisons and therapeutics, together with an appendix containing dietetic charts and biochemicalo data. Some might say that the section on psychiatry is almost disproportionately large for a book of this size, but, on the other hand, perhaps it reflects the new emphasis given to that subject in modern medicine.

This should be a popular textbook amongs medical students, who will find in it all they need to know for their qualifying examination in medice cine. It could also be read with profit and interes by more senior members of the profession and by those who, suffering from ' constructive specialization,' might feel the need of a thoroughly up-to-date textbook which is of reasonable length in order to widen their horizon.

R.D.G.

\section{FIRST STUDIES IN ANATOMY AND PHYSIOLOGY .}

By John CaIrney, D.Sc., M.D., F.R.A.C.S., and John CaIRney, B.Sc., M.B., Ch.B. Pp. 205, with I03 illustrations. Christchurch: N. M. Peryer Ltd. 1956. N.Z. price 30s. Agents in Great Britain: Lloyd-Luke (Medical Books) Ltd., 49 Newman Street, London, W.I.

An excellent introduction to the study of anatomy and physiology is made in this very welcome little book. It is beautifully produced, but what a pity its price is so high.

Sound advice is given in the first chapter, when the student is told 'to observe carefully the form of each new term you meet, and be sure you get its spelling right. It develops accuracy of observation.' Thus reading of the text is made more interesting 